\title{
Gender Differences in Implementing Organizational Change in Romania's Central Public Administration
}

\author{
Constantin M. Profiroiu \\ The Bucharest University of Economic Studies, Romania \\ profiroiu@gmail.com \\ https://orcid.org/0000-0002-1076-3744 \\ Alina G. Profiroiu \\ The Bucharest University of Economic Studies, Romania \\ alina.profiroiu@amp.ase.ro \\ https://orcid.org/0000-0001-5605-8736 \\ Corina C. Nastacă \\ The Bucharest University of Economic Studies, Romania \\ corina.nastaca@amp.ase.ro \\ https://orcid.org/0000-0002-3062-141X
}

Received: 12. 6. 2020

Accepted: 12. 4. 2021

\section{ABSTRACT}

The present study analyses the gender differences in implementing organizational change in Romania's central public administration, from a subordinates' perspective, in order to establish whether female leaders are more likely to adopt change in comparison to their male counterparts. The research methodology consists of an opinion survey conducted in the central public administration of Romania based on a questionnaire. The study reveals that female leaders are perceived in a positive, yet not in a better manner than men. They are considered transformational leaders capable of involvement in the process of organizational change of public institutions. There are no significant differences between the perceptions of men and women as leaders, although almost all the differences are in favour of men. The study shows a strong correlation between transformational leadership and leaders' capacity of implementing the management of change, the relationship being stronger in the case of female leaders who should continue to strengthen transformational behaviours.

Keywords: female leaders, female leadership advantage, organizational change, transformational leadership 


\section{Introduction}

Women have not always been perceived as suitable for leadership positions. In time, the perception about female leaders has changed and the topic has become attractive for researchers from different fields of study. Typically, the subject was treated in connection with phenomena like discrimination or stereotypes and concepts such as masculine values, the glass ceiling or gender segregation became prominent in many studies about gender, leadership, and discrimination conducted in the academic area and in other fields (see. Eagly, 2007; Eagly and Carli, 2003a, 2003b; Vecchio, 2002, 2003). The idea that women could use different leadership methods became rapidly the purpose of many studies which revealed contradictory results, ranging from the idea that women were not suited for being leaders because the female role was not congruent with the leader role (Eagly and Karau, 2002), to the point that women could become better leaders than men (Eagly, 2007; Eagly and Carli, 2003a, 2003b; Vecchio, 2002, 2003).

Many studies concluded that the qualities that female leaders exhibited and the leadership styles they used (primarily the transformational style) led to perceptions of women as efficient and better suited for leading modern organizations which present different characteristics from those in the past (Jogulu et al., 2006; Powell and Graves, 2003; Bass and Avolio, 1994; Eagly and Johnson, 1990, Eagly et al., 2003). Consequently, it is relevant to study perceptions about female leaders in the private sector as well as in the public administration in order to establish if women are considered suitable for leadership positions, and capable of assuming this role in an efficient and effective way. Such findings can enhance understanding of change generation and management in an environment extremely rigid to change and innovation.

In Romania, public administration is regarded as a feminine field where $66 \%$ of the public servants are women (National Agency of Civil Servants, 2019). Consequently, many leadership positions such as head of office, head of department or director, are occupied by female leaders (Рrofiroiu and Nastacă, 2018). This situation can have many causes. It could be a consequence of women's qualities, competencies and aptitudes in management or simply the presence of larger numbers of women among public servants. Many of them have raised through the ranks and reached senior positions in time.

In this context, the leadership styles of female leaders in public administration and their capacity of bringing change in a sector where innovation, progress, and modernization are hard to achieve due to the legal frame and bureaucracy, deserve to be studied. In addition, the role of female leaders in change management is important in the context of the public administration reform and this study will hopefully contribute to an exploration of factors at play in societies where reform is underway. Civil servants' perception about their female hierarchic superiors and these leaders' capacity of bringing change, could lead to improved understanding of female leaders' importance in the management of change and in the public administration reform. 


\section{Literature review}

\subsection{Leadership and gender: from incongruity to female leadership advantage}

The connection between leadership and gender was approached in many research papers and it is still a matter of interest because the perception about female leaders has changed considerably. Moreover, the number of women in positions of high decision in the private and public sector as well as in politics is higher than ever. Despite the progress that has been made, there are still fields where gender equity does not exist and occupational segregation is still present.

Authors as Powell and Butterfield (1994) concluded that the lower presence of women in powerful positions was not to be accounted by women's lack of training in management or leadership, by lack of professional experience or because of discriminatory labor legislation. Therefore, the answer might be related to the differences between men and women in the way they lead (Book, 2000; Helgesen, 1990; Loden, 1985; Rosener, 1995). Another cause could be the "glass ceiling", a set of "invisible barriers" which prevent many qualified women to achieve leadership positions in organizations because of their gender (Morrison, et al., 1987). Other explanations could be the double standards of evaluation of female leaders (Foschi, 1996, 2000) or the way society apprehends the leadership and gender issues.

Other factors that could explain the reduced number of female leaders are culture, the position of women in society and the opinion about female leaders which is affected by stereotypes and social values. All these aspects have influenced the perception of women's effectiveness as leaders. Theories such as the role congruity theory (Eagly and Karau, 2002) or the expectation states theory (Berger et al., 1977; Ridgeway, 1997, 2011) support the idea that women are undervalued as leaders and their effectiveness is perceived as lower than it really is.

The literature regarding leadership and effectiveness revealed contradictory results. Some authors (e.g., Carroll, 2006; Eagly, et al., 1992) considered that men were more effective leaders than women, while others (Bass and Avolio, 1994; Loden, 1985; Book, 2000; Helgesen, 1990; Rosener, 1995) suggested that women could become better leaders than men. The latter's theory was based on the assumption that men and women practiced different leadership styles. More recent theories brought into discussion the potential existence of the female leadership advantage, based on the fact that women might lead in ways that are particularly effective in contemporary organizations, which display different characteristics from the past (Eagly et al., 2003; Eagly, 2007; Eagly and Carli, 2003a, 2003b; Vecchio, 2002, 2003; Omar and Davidson, 2001).

Another important aspect that should be considered when studying gender and leadership is the presence of stereotypes. According to some authors (Abele, 2003; Bakan, 1966; Fiske and Stevens, 1993), society expects women 
to exhibit the so-called, communal traits. Society has associated women with qualities like modesty, kindness, tenderness, willingness to help and concern for others' well-being, which made them relationship-oriented. On the other hand, men have been perceived as being competent, aggressive, independent, decisive, and forceful. These are agentic traits that make them achievement-oriented (Abele, 2003; Bakan, 1966; Fiske and Stevens, 1993; Tost and Rosette, 2010). Therefore, such communal traits have disadvantaged women in leadership positions namely because that the image of a leader is automatically associated with the agentic traits exhibited by men (Eagly and Karau, 1991, 2002; Eagly, et al., 1995; Eagly, et al., 1992; Heilman, 2001). The fact that women's behavior is considered communal has caused a negative perception of female leaders because their gender role is considered incongruous with the leader role (Eagly and Karau, 2002). This incapacity of associating the image of a women with the image of a leader and research on role congruity, revealed that this perceived incompatibility has negative effects for women evaluation as regards leadership effectiveness (Eagly et al., 1995), leader emergence (Eagly and Karau, 1991), leadership abilities (Eagly et al., 1992), and the practiced leadership styles (Eagly and Johnson, 1990; Eagly and Johannesen-Schmidt, 2001; Eagly, et al., 2003).

In Romania's case, a valuable amount of studies addressing leadership and gender issues in the public administration could be identified, but they do not analyze either the leadership styles of men and women in the public administration' institutions, or the gender differences in the practiced leadership that might have positive impact on the management of change implementation, within these institutions. These researches aimed at identifying the causes of the lower representation of women in top management positions within the public institutions (Macarie and Moldovan, 2012) and focused predominantly on discrimination regarding access to public positions (Moldovan, 2016), investigating the presence of gender segregation in this area, or the reasons for women failures to break the glass ceiling and get access to decision-making positions related to the highest management levels (Macarie, 2006; Șandor et al., 2011; Macarie and Moldovan, 2012). Other studies analyzed the presence of women in positions with high power of decision in the Central Public Administration and their evolution during time with the purpose of revealing the presence of vertical and horizontal discrimination in this field and women success by breaking the glass ceiling and occupying the most important nonpolitical positions from the top management of the public institutions, such as Directors (Moldovan, 2016; Profiroiu and Nastacă, 2018).

Another research regarding the presence of women in leadership positions from the Romanian public administration institutions (Macarie et al., 2011) revealed that the majority of the respondents considered that only in some cases women and men have equal opportunities regarding access to the positions with high power of decision within the public institutions and the presence of gender stereotypes and prejudices against female leaders from this field. Also, the study revealed the disadvantages that women in leadership positions in the public institutions might have, such as: less time spent with 
family, stress, inevitable involvement in conflicts, taking responsibility for the team's mistakes, neglecting the time needed for rest, the hostile environment they have to face at certain times, less time spent in the organization than a man leader, excessive sensitivity and the fact that women give up faster when in a conflict (Macarie et al., 2011).

Other studies approached leadership and gender related to the organizational cultures (Macarie et al., 2008; Macarie et al., 2011) and the impact of organizational values (such as feminine and masculine values) on female leaders (Macarie and Moldovan, 2012). These studies revealed the most common obstacles encountered by women holding leadership positions, such as: the rigidity of the organizational culture, the indifference and apathy of the team, the need to demonstrate their skills and competences to their superiors, the outdated mentality, insufficient and incorrect information, lack of trust given by staff and superiors, which slows or blocks the communication process, resistance to change in organization, rejection of innovation and overcoming emotional reactions.

More than that, an important number of studies addressed the leadership topic in the Romanian public administration (Hințea, 2007; Stănescu and Roșca, 2010; Bibu and Moș, 2012; Țiclău, 2012; Mora and Țiclău, 2013; Hințea, 2015; Ticlău and Hințea, 2016; Nastacă, 2020; Рrofiroiu et al., 2020). Many of them analyzed the leadership styles practiced in the Romanian public administration, focusing on the transformational and transactional styles (Ticlău and Hințea, 2016; Filip, 2015; Țiclău et al., 2013; Stănescu and Roșca, 2010), without approaching the gender impact on the practiced leadership.

The relatively low number of studies linking leadership and gender in public administration in Romania created the opportunity to investigate whether women in public leadership positions have the necessary characteristics of efficient leaders, if they are perceived in a positive manner as being suitable to lead these institutions and to implement in a successful manner, the management of change. The originality of this research is that it focuses on the leadership styles of men and women from the Romania's Central Public Administration and their capacity of implementing the management of change.

\subsection{Transformational leadership and gender- the key to organizational change}

Transformational leadership is characterized by the fact that the leader motivates followers to put the collective interest first, considering that employees are one of the most important resources in the organization. For this reason, the leader takes responsibility for their professional development. The usage of this leadership style requires a great attention to values, emotions, and stimulation of human resources' creativity in order to find innovative solutions to solve problems (Bass, 1999; Bass and Avolio, 2000; Garcia Morales et al., 2008a, 2008b). A leader will try to develop a professional and emotional connection with his followers, trying to inspire them and help them embrace the mission and organizational values. The transformational leader will use 
charisma to gain the trust of his subordinates and inspire them, showing them why it is important to have a joint mission, giving a purpose, direction and meaning to their work (Bass, 1999). Organizational objectives are very important for this leader who will try to develop among his followers, the notion of commitment needed to achieve these goals and the best possible results (Bass, 1999; Bass and Avolio, 2000). Other characteristics of transformational leadership include promoting the idea of innovation in the organizational culture, searching and disseminating the best knowledge that can lead to increased organizational performance (Bass, 1999; Bass and Avolio, 2000). This leader is an adept of the intellectual stimulation of his followers, promoting lifelong learning, knowledge building, skills and competence development for employees to have different perspectives and find new solutions to prevent or solve organizational problems. This leader inspires his followers, shows them the trust and respect he has for the organization and culture, is proud to be associated with his organization, and will use charisma to generate these kinds of emotions and feelings among his followers (Bass, 1999; Conger, 1999; Bass and Avolio, 2000).

The leader encourages his followers to trust themselves, their leaders and their organization, motivates, develops a very good communication relationship and has high expectations of his followers (Bass, 1999; Bass and Avolio, 2000; Conger, 1999).

This leadership style is characterized by four dimensions that correlate between them: charisma or the idealized influence, inspirational motivation, intellectual stimulation and individualized consideration (Burns, 1978; Bass, 1985, 1998; Bass and Avolio, 1993).

The transactional leadership focuses on exchanges between leaders and their subordinates, the existing relationship between them being a cost-benefit relationship (Bass 1985, 1998, 2000, 2008; Burns, 1978). The central idea of this style of leadership is the transaction that takes place between leaders and followers. The relationship entails costs and benefits for both sides (Kuhnert and Lewis, 1987). As far as leaders are concerned, these exchanges enable them to meet their performance targets, to solve their tasks, motivate their subordinates, implement contractual provisions, find reward methods, avoid risks and focus on improving the organization's efficiency (McCleskey, 2014). As regards subordinates, this style enables them to fulfil their own interests and to focus on achieving organizational objectives such as increasing services and products' quality, reducing costs and increasing production (Sadeghi and Pihie, 2012).

As a result of this exchange relationship, subordinates will receive what they need (usually financial benefits) assuming that the leader is the one who knows the needs of his subordinates and what are the methods that motivate them the most. In order for the practice of this style of leadership to have positive effects, such as increasing efficiency or organizational performance, it is necessary that the group of followers to be motivated by this system of rewards and sanctions and recognize the leader's position of authority (Kuhnert, 1994; Mora and Ţiclău, 2013). 
In the case of transactional leadership, followers are motivated by the leader's promises, his praise and the rewards they receive. Deviations are corrected by negative feedback or disciplinary sanctions. The leaders react when their followers achieve what they have "transacted". In the type of behavior called the contingency reward, leaders either plot tasks or consult with their followers about what needs to be done, promising rewards and allocating the necessary resources. When leaders engage in active behavior (active management- by exception) they oversee the performance of their subordinates and correct their mistakes. When leaders engage in passive behavior (passive management- by exception), they will expect to be made aware of the mistakes made by subordinates and then take steps to correct them, giving negative feedback or reprimands (Bass and Steidlmeier, 1999).

The fact that the relationship between leaders and followers is based on exchange, does not only mean the extrinsic motivation of subordinates. Transactional leaders not only use material rewards, but depending on the needs and expectations of their subordinates, they provide the support they need. If the subordinate needs more intrinsic motivation, then the leader will also try to satisfy these needs, through recognition of merits, praise and respect shown for the work done.

The gender impact on leadership styles was emphasized in research about transformational and transactional leadership. Studies showed that transformational leaders exhibited "communal" traits, like individualized consideration and consequently, this style seemed to be more related to women (Eagly and Johannesen-Schmidt, 2001, p. 787). Authors (Van Engen et al., 2001, p.74) named this leadership style a "feminine" one because it focused on the "intellectual stimulation of the leader and the individualized consideration given to subordinates", aspects considered to be attributes of the feminine gender.

These studies about transformational leadership style showed that the communal traits exhibited by female leaders had positive effects for contemporary organizations and could lead to female leadership advantage (Bass and Avolio, 1994; Dezso and Ross, 2008; Lowe and Kroeck, 1996). Another argument in favor of the female leadership advantage was generated by research on double standards of competence (Foschi, 1996, 2000; Tost and Rosette, 2010). The double standards of competence theory suggested that women in top management might receive favorable evaluations of their leadership abilities because performing such highly masculine roles meant they have already provided information about their abilities and must have been very competent to have attained success in a role that requires usually agentic traits.

Despite many studies on transformational and transactional styles, results remain inconclusive. Eagly et al.'s (2003) findings provided a better picture of the relation between gender and leadership styles. The results showed that women are more transformational and more committed to rewarding their employees (which is transactional leadership component) than men are and men's behavior was associated more often than women's with passive leadership styles: management by exception (active and passive) and laissez-faire. 
Although these differences between the leadership styles of men and women were small, authors showed that dominated in the whole study.

However, Kanter (1977) assumed that when women and men occupy the same hierarchic position they behave in similar ways, considering that they have the same leadership role. It follows that the differences between female and male leaders can be minimized or absent when they occupy the same hierarchic position. This situation may not become manifest in practice because gender roles continue to influence their behavior (Eagly and JohannesenSchmidt, 2001).

These findings are important for measuring the perception about women and their capability of bringing change into organizations. If women are considered more transformational than men and transformational leaders are the most capable of bringing change into organizations (Bass, 1999), then female leaders should be perceived more positively as more capable of embracing and developing the change process, inclusively in public organizations.

\subsection{Female leaders and the management of change}

In a continuously changing environment, it is impossible for organizations to survive, evolve and compete without embracing and implementing change on a daily basis. Continuous change in an organization requires "frequent, purposeful adjustments that are small but ongoing and cumulative in effect" (Weick and Quinn, 1999; Carter et al., 2012, p. 942, Brown and Eisenhardt, 1997).

Bass and Avolio, (1994) believed that women were transformational leaders, capable of bringing change in today's organizations which need to adapt in a continuously changing and evolving environment. The private sector has the necessary means to keep up with the continuous internal and external changes, but public administration is held on by bureaucracy, legislation, and an inflexible organizational culture. In this context, female leaders from public administration have to modernize a system conducted in an old fashion way, recognized for its resistance to change. Therefore, the transformational traits that women exhibit should address the precise needs of public administration institutions in order to achieve organizational change.

Studies on the subject showed that organizational change should be approached from both employees' and leaders' perspectives. Both sides should adapt their behavior in order to implement and maintain a changing process, until the moment when organizational change becomes a normal and usual phenomenon.

Feldman and Pentland (2003) argued that employees should modify both their work routines and social practices (such as attitudes and relations with managers and colleagues), in order to sustain the process of continuous change. Therefore, they must preserve the most effective work practices and integrate them with new and more efficient ones, in order to cope with the challenge of daily adaptation to change. As a consequence, employees often 
face difficulties and tensions because they try to maintain their level of performance and at the same time, adapt to their new job requirements (Kanfer and Ackerman, 1989).

In the changing process, employees need support from their superiors, because they must adapt to the new realities of their work while being efficient and maintaining organizational performance, so superiors must act more like leaders and less like managers. (Bass and Riggio, 2006). Studies concerning leadership styles and organizational change showed a correlation between transformational leadership and effective management during the change process (Pawar and Eastman, 1997; Bass and Riggio, 2006). This happens because leaders who use transformational style are the only ones who "recognize the need for change, create and share compelling visions with employees, guide them through adaptations, and inspire them to accomplish the challenging goal of institutionalizing change" (Carter et al., 2012, p. 942; Bass, 1999).

Transformational leaders inspire, motivate, help employees to embrace change, to understand the importance of performance as well as the opportunities of developing their careers, raise the self-confidence, following the team's interest rather than the self-interest (Bass, 1999). Transformational leaders coach and guide, they raise respect and trust and consequently develop a strong relationship with employees (Liu and Batt, 2010). More than that, social exchange theory (Blau, 1964) considers that employees' behaviors are influenced by tangible and intangible rewards from their leaders (Graen and Uhl-Bien, 1995; Wilson, et al., 2010). On one hand, employees need financial rewards, but on the other hand they will behave in a certain manner if the leaders trust them, inspire, teach them or have understanding and supportive attitudes. Consequently, employees who developed good relationships with their hierarchic superiors should be more efficient, will achieve performance and will feel part of a team so they will support their managers and colleagues (Cropanzano and Mitchell, 2005). Other studies considered that high-quality relationships with the hierarchic superiors lead to performance (Gerstner and Day, 1997; Howell and Hall-Merenda, 1999) and organizational change behavior (llieș et al., 2007).

In conclusion, employees led by transformational leaders should react favorably to change as regards both their attitude and behavior, because of the powerful influence exerted by leaders.

\section{Research Methodology}

The present study is underpinned by a series of theories regarding the gender differences in leadership styles (Carroll, 2006; Eagly et al., 1992; Bass and Avolio, 1994; Loden, 1985; Book, 2000; Helgesen, 1990; Rosener, 1995), the transformational and transactional leadership styles (Bass and Avolio, 1994), the relation between organizational change and transformational leaders (Bass, 1999) and on the idea that women and men behave similarly when occupying the same leadership positions (Kanter, 1977). 


\subsection{Aim and objectives of the research}

The aim of the study is to measure civil servants' perception about the role of female leaders in Romania's Central Public Administration in supporting and managing organizational change. The research process has tried to establish if female leaders are perceived as being more open towards the process of change or in a similar manner with male leaders, and if they are considered visionary transformational leaders who can bring novelty inside an inflexible and change-resistant system.

The main objectives of the study are:

Ob.1: To investigate the gender differences regarding leaders' capacity of implementing the management of change in Romanian Central Public Administration.

Ob.2: To establish if leaders' gender is a variable which influences the perception about their capacity of bringing organizational change.

Ob.3: To establish if the leadership style practiced predominantly in the public administration is the transformational one which would make the organizations more open to change.

Ob.4: To explore civil servants' perception about the organizational change implementation' phase in public institutions.

\subsection{Research design and data collection}

The research methodology consists of an opinion survey which has been conducted using a questionnaire. The questionnaire was built by the authors and it was designed specifically for the Central Public Administration' authorities. Its purpose was to measure the civil servants' perception about their leaders' capacity of bringing change into the public administration, as well as about the change implementation phase underway in public institutions. The civil servants were asked to express their opinion regarding the attitude and behavior of their Directors/General Directors.

The institutions in the sample were selected through a convenience sampling method, which included the most accessible persons for research participation. The questionnaires were applied in 13 Ministries, four subordinated institutions in Romanian Central Public Administration and the General Secretariat of Government's Office.

The questionnaire consists of three parts. The first part contains six identification questions: age, the hierarchic position, seniority into the institution, seniority into the public function, gender, gender of the Director/General Director, as well as two questions about public servants' preference regarding their leaders' gender.

The second part contains four questions designed to measure the perception about leaders' capacity of bringing change into public institutions in view of 
establishing if female leaders were more open towards change. The perception of the civil servants was measured through four dimensions: the attitude towards the human resource, the attitude towards change, the attitude with regard to the new problems and the practiced leadership styles. Each dimension included between four and eleven sub items which presented specific behaviors that Directors' might exhibit in the leading process.

The attitude towards the human resource was measured using ten items that presented leadership behaviors which characterize the relationship between leaders and their' subordinates. The respondents were asked to evaluate the frequency of these behaviors in leaders' general attitudes.

The attitude with regard to the new problems was measured by ten items that represented leadership behaviors which leaders might exhibit in face of new problems and in the solving process. In this case too, respondents were asked to evaluate the frequency of these behaviors in leaders' general attitudes. The items used for measuring these two dimensions are leadership behaviors specific to transactional and transformational leaders and were built based on the characteristics identified in the literature review concerning these leadership styles. The items were built starting from these theories, being adapted to the specificities of the public administration.

The items from the questionnaire are presented in section 3.2.1 along with the study's results. The practiced leadership styles dimension was measured using 11 sub items which were built in accordance with Burns, (1978), Bass and Avolio (1985) theories about transformational and transactional leadership styles. The questions measuring the practiced leadership do not replicate the items from the instrument created by Bass and Avolio to measure leadership and its outcomes (the Multifactor Leadership Questionnaire) (Bass, 1985; Hater and Bass, 1988; Bass and Avolio, 1990, 1993, 1994), but they were built starting from the characteristics of the transformational and transactional leaders, as presented in their theories (Burns, 1978; Bass, 1985, 1998, 2000, 2008; Avolio, 1999; Avolio and Bass, 2004; Bass and Avolio, 1993). Also, it should be mentioned that these leadership styles cannot be exhibited in the same manner as in the private organizations, consequently all the items were built considering public institutions specific characteristics. The sub items contained eight behaviors exhibited by transformational leaders, as well as two behaviors exhibited by transactional leaders. In order to create a more comprehensive picture of the leaders in the sample, a sub item which described a form of passive leadership was included.

The reason why the questionnaire's items were built based on the theories of the transformational and transactional leadership is that these styles are connected with organizational change process.

The attitude toward change dimension was measured through four questions regarding leader's behaviors concerning the process of change in the public institution and gender's impact on the organizational change process. These questions are meant to investigate civil servants' personal opinions. The items used in the questionnaire are presented in section 3.2.1 along with the results. 
All the questions were designed to measure the frequency of the mentioned situations and behaviors in the leaders' general attitudes, using the Likert scale. The civil servants were asked to rate their' leaders' behaviors in those situations on a scale from one to five where the scale meant: 1-not at all, 2- to a small extent, 3- to a medium extent, 4- to a high extent, 5-to the highest extent. The five mentioned items from the scale are explained as it follows: 1 and 2 (not at all and to a small extent) represent a negative perception of the civil servants, 4 and 5 (to a high and to the highest extent) means that respondents have a positive perception related to their leaders and 3 (to a medium extent) represents a neutral perception.

The third part of the questionnaire contained two closed questions concerning the opinion of the civil servants with regard to the changing phase in which the public institution was as well as the changes that have been implemented.

\subsubsection{Data collection}

The questionnaire was administrated via email between January and June 2019. The civil servants voluntarily filled in the questionnaire after being assured of confidentiality and anonymity. The collected data were processed in SPSS. The results were used to validate the hypothesis of the study and to answer the research objectives.

Based on the literature review regarding the gender differences in leadership and especially on the studies regarding transformational leadership and gender, the following hypothesis have been designed:

H1: As female leaders are considered to exhibit transformational behaviors more than men, consequently they should be perceived as being more open toward implementing change management process.

H2: Civil servants' perception on their leaders' capacity of implementing the management of change will be influenced by leaders' gender.

H3: The most exhibited leadership style in the Central Public Administration is the transformational one which will influence the process of organizational change.

H4: If civil servants' will perceive their leaders as being transformational leaders, it will be observed that they appreciate that the public institutions started to implement the change process.

\subsubsection{The main characteristics of the sample}

In the Romanian Civil Service, based on the level of powers and attributions, the public functions are divided in: public functions corresponding to senior (high) civil servants, management public functions and execution public functions. The execution public functions are structured in professional grades based on the seniority in the occupied public position as it follows: beginner, assistant, principal and superior grade, which is the maximum level (The Administrative Code, 2019). 
For the present research, the sample was formed by execution public servants and civil servants in management positions. 200 civil servants from 18 institutions responded to the questionnaire.

Regarding the structure of the sample, all the respondents occupied general class I public functions (university education at graduate level at the very least). The civil servants from management occupied positions of head of office and head of department, positions related to the middle and first -line management levels. The civil servants from the sample evaluated their Directors/General Directors' behaviors (leadership positions from the top management of the studied institutions) and not the behaviors of their direct hierarchic superiors.

As regards respondents' responsibilities, 181 (90.5\%) were execution civil servants and 18 (9.5\%) were civil servants in management positions. In terms of professional expertise, 12 respondents (6.06\%) were beginners, 55 (27.78\%) were assistants, 19 (9.60\%) were middle officers (principal grade) and $112(56.57 \%)$ were senior officers (superior grade) with over 7 years of experience in the public administration. Only two respondents preferred not to mention their professional grades.

As far as the tenure in the institution was concerned, $8 \%$ (16 respondents) had up to one year of experience, 30\% (60 respondents) had between one and five years of experience, $9 \%$ (18 respondents) had between 5 and 7 years of experience and 53\% (104 respondents) had over 7 years of experience.

Regarding the gender distribution of the respondents, $81 \%$ (162) were women and $19 \%$ (38) were men. $69 \%$ of the respondents (138) had women as Directors/General Directors and for $31 \%$ (62) the position was occupied by men.

\section{Data analysis and main findings of the study}

\subsection{Data analysis}

The collected data was coded and introduced in SPSS. The data were as analyzed using Descriptive Statistics, Compare Means, as well as Linear Regression and Correlation functions. All the results were analyzed by comparing the means between the answers of the civil servants who were led by females and the ones who were led by males.

\subsection{Main findings of the study}

\subsubsection{Female leaders' capacity of implementing organizational change}

The following section presents the results of the study as well as the hypothesis validation. At the beginning of the questionnaire the civil servants were asked about their preference regarding the Director's gender. Only 10\% (21) wanted to be led by a female leader while 19\% (37) preferred to be led by a man. For the majority of the respondents (71\%), the leaders' gender was irrelevant. 
The civil servants were also asked if they consider that the head of the institution in which they worked should be a man or a woman. The majority $(73 \%)$ considered that gender was not important. Only $7 \%$ (14) considered that their institutions should be led by female leaders and 20\% (41) by male leaders.

In the first section of the analysis, for each dimension through which the perception of the civil servants was measured (the attitude towards the human resource, the attitude towards change, the attitude in regard to the new problems and the practiced leadership styles), the responses of the civil servants were compared in terms of the Director's/General Director's gender in order to observe if there were significant differences between the opinions of the two groups. After comparing the means for each sub item of the four dimensions, composite variables were calculated for each dimension in order to observe if female leaders scored higher than men or not. After comparing the means between the two groups another composite variable (Variable Capacity of Change-VOC) was created by computing the average between the scores obtained by leaders on the four dimensions. The purpose was to compare the differences between the two groups concerning civil servants' perception of their leaders' capacity to implement the management of change within the public institutions from the sample. In order to test the first hypothesis (Female leaders are more open towards the change process), the Independent Samples T-Test was used.

Table 1: Comparison of perception regarding the attitude towards human resources

\begin{tabular}{|c|c|c|c|}
\hline \multirow{2}{*}{ Attitude towards human resource } & \multicolumn{3}{|c|}{ Director's gender } \\
\hline & $\mathrm{F}$ & M & Differences \\
\hline Rewards subordinates according to their performance & 3.25 & 3.47 & 0.22 \\
\hline Involves subordinates in solving problems & 4.17 & 4.21 & 0.04 \\
\hline Listens to and appreciates the ideas of the execution public servants & 3.91 & 3.94 & 0.03 \\
\hline $\begin{array}{l}\text { Discusses constantly to his/her subordinates about their problems } \\
\text { and those of the institution }\end{array}$ & 3.54 & 3.76 & 0.22 \\
\hline $\begin{array}{l}\text { Treats the problems of the subordinates, directly and according to } \\
\text { everyone's needs. }\end{array}$ & 3.60 & 4.00 & 0.4 \\
\hline $\begin{array}{l}\text { Encourages and allows subordinates to participate in training } \\
\text { courses abroad }\end{array}$ & 3.46 & 3.34 & 0.12 \\
\hline Organizes exchanges with other home or foreign institutions. & 3.01 & 3.19 & 0.18 \\
\hline $\begin{array}{l}\text { Encourages and takes measures to increase the number of experts } \\
\text { and specialists from the directorate he/she is leading }\end{array}$ & 3.60 & 3.63 & 0.03 \\
\hline $\begin{array}{l}\text { The public servants from the institution are proud to be associated } \\
\text { with the image of the institution }\end{array}$ & 3.67 & 3.85 & 0.18 \\
\hline Uses non-financial motivation techniques & 3.25 & 3.44 & 0.19 \\
\hline
\end{tabular}

Source: authors 
It could be observed that there were no significant statistical differences between the two groups under analysis (0.03- 0.22 points). For 9 of the sub items, the differences were in favor of male leaders while women scored higher for one sub item only. The comparison showed that the civil servants considered that their leaders behave almost in the same manner in relation to human resources, exhibiting the specific behaviors from a medium to a high extent.

\section{Table 2: Comparison of perception concerning the attitude with regard to the new problems}

\begin{tabular}{|c|c|c|c|}
\hline \multirow{2}{*}{ The attitude with regard to the new problems } & \multicolumn{3}{|c|}{ Director's gender } \\
\hline & $\mathrm{F}$ & M & Differences \\
\hline Uses brainstorming for problem-solving & 3.19 & 3.23 & 0.04 \\
\hline Makes decisions after consultation with the subordinates & 3.34 & 3.42 & 0.08 \\
\hline Is open for innovative solutions which can bring change into the institution & 3.72 & 3.92 & 0.2 \\
\hline $\begin{array}{l}\text { Uses innovative solutions, different from the solutions applied to the old } \\
\text { problems }\end{array}$ & 3.53 & 3.71 & 0.18 \\
\hline Solves problems in a manner which can generate long term changes & 3.57 & 3.89 & 0.32 \\
\hline Initiates innovative projects in order to prevent new problems & 3.54 & 3.82 & 0.28 \\
\hline $\begin{array}{l}\text { Implements innovative projects in order to prevent the occurrence of new } \\
\text { problems in the long term }\end{array}$ & 3.56 & 3.82 & 0.26 \\
\hline $\begin{array}{l}\text { Prefers to make decisions by herself/himself without taking into account } \\
\text { the opinion of her/his team. }\end{array}$ & 2.85 & 2.97 & 0.12 \\
\hline $\begin{array}{l}\text { Organizes meetings with the subordinates in order to debate the emerging } \\
\text { problems. }\end{array}$ & 3.55 & 3.65 & 0.1 \\
\hline Includes the opinions of the civil society in his/her decisions. & 3.11 & 3.39 & 0.28 \\
\hline
\end{tabular}

Source: authors

As far as the perception concerning leaders' attitude with regard to emerging problems, there were no significant differences between the two groups (0.01-0.32 points). Male leaders tended to score higher than women did to all presented items but it could not be established whether they treated the new problems differently from women. Both groups exhibited that behavior to a small or medium extent. The data showed that the civil servants considered that both types of leaders exerted the mentioned behaviors from a medium to a high extent, except for one case. 
Table 3: Comparison of perception regarding the practiced leadership styles

\begin{tabular}{|c|c|c|c|}
\hline \multirow{2}{*}{ The practiced leadership styles } & \multicolumn{3}{|c|}{ Director's gender } \\
\hline & $\mathrm{F}$ & M & Differences \\
\hline $\begin{array}{l}\text { He/she involves in solving problems only when they got very } \\
\text { serious (passive) }\end{array}$ & 2.64 & 2.85 & 0.21 \\
\hline Prefers to prevents rather than solve (transformational) & 3.61 & 3.68 & 0.07 \\
\hline $\begin{array}{l}\text { Appoints explicit assignments to the subordinate civil servants. } \\
\text { (transformational) }\end{array}$ & 3.93 & 4.13 & 0.2 \\
\hline $\begin{array}{l}\text { Pursues the errors, mistakes, irregularities or deviations of the } \\
\text { subordinates. (transactional) }\end{array}$ & 3.59 & 3.90 & 0.31 \\
\hline $\begin{array}{l}\text { He/She is interested in the necessities of every subordinate. } \\
\text { (transformational) }\end{array}$ & 3.53 & 3.76 & 0.23 \\
\hline $\begin{array}{l}\text { Considers that every person from his/her team has different needs, } \\
\text { expectations, and competencies. (transformational) }\end{array}$ & 3.67 & 3.73 & 0.06 \\
\hline $\begin{array}{l}\text { He/ She confident that the objectives of the organization can be } \\
\text { achieved. (transformational) }\end{array}$ & 4.11 & 4.06 & 0.05 \\
\hline Uses satisfying managing daily activities. (transformational) & 3.62 & 3.85 & 0.23 \\
\hline $\begin{array}{l}\text { Rewards the execution civil servants through non-financial } \\
\text { instruments. (transactional) }\end{array}$ & 3.15 & 3.23 & 0.08 \\
\hline Suggests new approaches of solving problems. (transformational) & 3.54 & 3.76 & 0.22 \\
\hline Involves directly in solving the problems. (transformational) & 3.99 & 4.18 & 0.19 \\
\hline
\end{tabular}

Source: authors

In order to observe the leadership styles used in the public institutions, 11 behaviors were presented to the sample asking them to rate their leaders' attitude on a scale from 1 to 5 . The results showed no significant differences (0.07-0.31 points) between the attitudes of men and women. The small differences were in favor of male leaders, apart from one case: the transformational behavior, namely inspiring confidence in goal achievement. The results were partially in accordance with Eagly et al. (2003) who stated that men tend to be associated more often with the passive leadership behavior while „women are more transformational and more committed to rewarding their employees" (p.578) which was not proven in this case. In the present situation, the differences between the leadership styles of men and women were small, but in favor of male leaders, which was in contrast with Eagly et al. (2003) who observed that gender differences were small, but in women's favor. 
Table 4: Comparison of perception regarding the attitude towards change

\section{The attitude towards change}

Do you believe that your leader has been implementing changes since he/she has occupied this position?

Do you evaluate that the changes implemented by your Director as being positive?

Do you believe that your director is leading in a different manner than the old one?

Do you believe that the director's gender influences the organizational change?

\begin{tabular}{|c|c|c|}
\hline \multicolumn{3}{|c|}{ Director's gender } \\
\hline F & M & Differences \\
\hline 3.41 & 3.37 & 0.04 \\
\hline 3.43 & 3.56 & 0.13 \\
\hline 3.47 & 3.56 & 0.07 \\
\hline 2.88 & 3.04 & 0.16 \\
\hline
\end{tabular}

Source: authors

Regarding the attitude towards change, female leaders scored higher at the first subitem but for the whole dimension, the differences between the two groups were not significant. The civil servants' opinion was that the director's gender influences the organizational change process only to a medium extent.

Table 5: Comparison of perception regarding the four dimensions of the organizational change

\begin{tabular}{|l|c|c|c|c|c|}
\hline & $\begin{array}{c}\text { Director's } \\
\text { gender }\end{array}$ & $\mathbf{N}$ & Mean & $\begin{array}{c}\text { Std. } \\
\text { Deviation }\end{array}$ & $\begin{array}{c}\text { Std. Error } \\
\text { Mean }\end{array}$ \\
\hline Attitude towards human resource (V1) & F & 138 & 3.5449 & .98448 & .08380 \\
\hline $\begin{array}{l}\text { Attitude with regard to new problems } \\
\text { (V2) }\end{array}$ & M & 62 & 3.6823 & .92851 & .11792 \\
\hline & M & 138 & 3.3949 & .95584 & .08137 \\
\hline Practiced leadership styles (V3) & F & 137 & 3.5806 & .83780 & .10640 \\
\hline & M & 62 & 3.7390 & .83360 & .10587 \\
\hline Attitude towards change (V4) & F & 138 & 3.3007 & 1.10414 & .09399 \\
\hline & M & 62 & 3.3871 & 1.15382 & .14654 \\
\hline
\end{tabular}

Source: authors 
Table 6: The Independents Samples T-Test's results

\begin{tabular}{|c|c|c|c|c|c|c|c|c|c|c|}
\hline \multicolumn{11}{|c|}{ Independent Samples Test } \\
\hline & \multirow{3}{*}{$\mathrm{F}$} & \multicolumn{2}{|c|}{$\begin{array}{l}\text { Levene's } \\
\text { Test for } \\
\text { Equality of } \\
\text { Variances }\end{array}$} & \multicolumn{7}{|c|}{ t-test for Equality of Means } \\
\hline & & \multirow[t]{2}{*}{ Sig. } & \multirow[t]{2}{*}{$\mathrm{t}$} & \multirow[t]{2}{*}{$d f$} & \multirow{2}{*}{$\begin{array}{c}\text { Sig. } \\
\text { (2-tailed) }\end{array}$} & \multirow{2}{*}{$\begin{array}{c}\text { Mean } \\
\text { Difference }\end{array}$} & \multirow{2}{*}{$\begin{array}{c}\text { Std. Error } \\
\text { Difference } \\
\text { Lower }\end{array}$} & \multicolumn{3}{|c|}{$\begin{array}{l}95 \% \text { Confidence Interval } \\
\text { of the Difference }\end{array}$} \\
\hline & & & & & & & & Upper & & \\
\hline V1 & $\begin{array}{l}\text { Equal } \\
\text { variances } \\
\text { assumed }\end{array}$ & .860 & .355 & -.928 & 198 & .354 & -.13733 & .14793 & -.42906 & .15440 \\
\hline V2 & $\begin{array}{l}\text { Equal } \\
\text { variances } \\
\text { assumed }\end{array}$ & .985 & .322 & -1.319 & 198 & .189 & -.18572 & .14083 & -.46343 & .09199 \\
\hline V3 & $\begin{array}{l}\text { Equal } \\
\text { variances } \\
\text { assumed }\end{array}$ & .002 & .969 & -1.212 & 197 & .227 & -.15838 & .13063 & -.41599 & .09923 \\
\hline V4 & $\begin{array}{l}\text { Equal } \\
\text { variances } \\
\text { assumed }\end{array}$ & 1.022 & .313 & -.505 & 198 & .614 & -.08637 & .17119 & -.42396 & .25121 \\
\hline
\end{tabular}

Source: authors

The T-Test showed that the first hypothesis (As female leaders are considered to exhibit transformational behaviors more than men, consequently they should be perceived as being more open toward implementing change management) was not validated, considering that the level of Significance was higher than 0.05 which meant that there were no significant differences between the two groups. The civil servants considered that their leaders' capacity of bringing change was almost the same irrespective of gender. The results were in accordance with Kanter's theory (1977) who states that women and men who occupy the same hierarchic position behave in similar ways, due to fulfilling the same leadership role.

Even if female leaders scored less, on the whole, it could be observed that they were evaluated in a positive manner by their' subordinates. The findings are in line with the double standards of competence theory (Foschi, 1996, 2000) which states that women from top management might receive favorable evaluations about their behavior because performing these highly masculine roles meant that they had already provided information about their abilities and must have been very competent to occupy positions with such high power of decision, generally associated with masculine gender. 


\subsubsection{Gender influence on the organizational change process}

The second section of the analysis presents the relationship between organizational change and leaders' gender. Even if the previous showed that both female and male leaders are perceived in a similar manner, civil servants' opinion on gender influence needs to be further investigated. In order to test the second hypothesis (Civil servants' perception on their leaders' capacity of implementing the management of change will be influenced by leaders' gender.), a correlation between the composite Variable Organizational Change and civil servants' answers about gender influence on the organizational change has been computed. The results showed that despite perceptions of similar behavior regard gender, the civil servants considered gender as a variable which influenced the process of change. The findings could indicate the presence of stereotypes (Abele, 2003; Bakan, 1966; Fiske and Stevens, 1993) that lead to different expectations and opinions in regard to leader's behavior according to their gender.

Table 7: Correlation between leaders' gender and their capacity to implement change

\begin{tabular}{|c|c|c|c|c|}
\hline \multicolumn{5}{|c|}{ Correlations } \\
\hline \multicolumn{3}{|c|}{ Director's gender } & $\begin{array}{l}\text { The perception of } \\
\text { gender influence on }\end{array}$ & VOC \\
\hline \multirow{6}{*}{$\mathrm{F}$} & \multirow{3}{*}{$\begin{array}{l}\text { The perception of } \\
\text { gender influence on } \\
\text { organizational change. }\end{array}$} & $\begin{array}{l}\text { Pearson } \\
\text { Correlation }\end{array}$ & 1 & $.429^{* *}$ \\
\hline & & Sig. (2-tailed) & & .000 \\
\hline & & $N$ & 138 & 137 \\
\hline & \multirow{3}{*}{ VOC } & $\begin{array}{l}\text { Pearson } \\
\text { Correlation }\end{array}$ & $.429^{* *}$ & 1 \\
\hline & & Sig. (2-tailed) & .000 & \\
\hline & & $\mathrm{N}$ & 137 & 137 \\
\hline \multirow{6}{*}{ M } & \multirow{3}{*}{$\begin{array}{l}\text { The perception of } \\
\text { gender influence on } \\
\text { organizational change. }\end{array}$} & $\begin{array}{l}\text { Pearson } \\
\text { Correlation }\end{array}$ & 1 & $.510^{* *}$ \\
\hline & & Sig. (2-tailed) & & .000 \\
\hline & & $\mathrm{N}$ & 62 & 62 \\
\hline & \multirow{3}{*}{ VOC } & $\begin{array}{l}\text { Pearson } \\
\text { Correlation }\end{array}$ & $.510^{* *}$ & 1 \\
\hline & & Sig. (2-tailed) & .000 & \\
\hline & & $\mathrm{N}$ & 62 & 62 \\
\hline
\end{tabular}

Source: authors 
The data indicate a relationship between the leaders' capacity of implementing organizational change and their' gender, which validated the second hypothesis. The relation is a moderately positive one. The results showed that the civil servants considered that the Directors' gender could influence their' capacity of bringing organizational change even if they did not express this belief when they evaluated their leaders' behaviors.

\subsubsection{Transformational leaders and organizational changing process}

In the next section, the third hypothesis (The most exhibited leadership style in the Central Public Administration is the transformational one which will influence the process of organizational change) was tested, using a regression model. The purpose was to investigate, a likely relation between the capacity of change (namely VOC variable) and the practiced leadership styles. The hypothesis validates as the results showed that the most frequently exhibited behavior was the transformational one. In addition, a strong relation between transformational leadership and the capacity of change was established. The data also showed the potential existence of the female leadership advantage. Even if currently women and men present almost the same leadership behavior, the higher impact of transformational behavior on women's capacity to implement change revealed by the regression model may indicate that in the future, women might be perceived as being better leaders than men

Table 8: Comparison between the leadership styles exhibited by gender

\begin{tabular}{|c|c|c|c|}
\hline & Gender of the Director & Mean & Std. Deviation \\
\hline \multirow{4}{*}{$\mathrm{F}$} & VOC & 3.4518 & .84695 \\
\hline & Transformational behavior & 3.7482 & 1.03489 \\
\hline & Transactional behavior & 3.3759 & .97162 \\
\hline & Passive behavior & 2.65 & 1.337 \\
\hline \multirow{4}{*}{ M } & VOC & 3.5973 & .79755 \\
\hline & Transformational behavior & 3.8931 & .96317 \\
\hline & Transactional behavior & 3.5645 & 1.01418 \\
\hline & Passive behavior & 2.85 & 1.377 \\
\hline
\end{tabular}

Source: authors

The data show that the leaders in the sample exhibited primarily transformational behaviors, followed by transactional behaviors. The differences between groups were not significant and were in men's favor. It could be observed that men scored higher in passive behavior, too. It could also be observed that men also scored higher at the capacity of implementing the management of change. The civil servants considered that their leaders were capable of changing the organization from a medium to a high extent. Even 
if women did not score higher, they were perceived in a positive manner as being capable of implementing change almost as men were. The findings are important considering the process of public administration reform as the leaders are perceived as being opened to change, trying to use innovation and new ways of managing.

Table 9: Correlation between leadership behaviors and leaders' capacity to implement organizational change

\begin{tabular}{|c|c|c|c|}
\hline \multicolumn{3}{|c|}{ Director's gender } & VOC \\
\hline \multirow{12}{*}{$\mathrm{F}$} & \multirow{4}{*}{$\begin{array}{l}\text { Pearson } \\
\text { Correlation }\end{array}$} & VOC & 1.000 \\
\hline & & Transformational behavior & .908 \\
\hline & & Transactional behavior & .784 \\
\hline & & Passive behavior & -.261 \\
\hline & \multirow{4}{*}{ Sig. (1-tailed) } & VOC & \\
\hline & & Transformational behavior & .000 \\
\hline & & Transactional behavior & .000 \\
\hline & & Passive behavior & .001 \\
\hline & \multirow{4}{*}{$N$} & VOC & 137 \\
\hline & & Transformational behavior & 137 \\
\hline & & Transactional behavior & 137 \\
\hline & & Passive behavior & 137 \\
\hline \multirow{12}{*}{ M } & \multirow{4}{*}{$\begin{array}{l}\text { Pearson } \\
\text { Correlation }\end{array}$} & VOC & 1.000 \\
\hline & & Transformational behavior & .793 \\
\hline & & Transactional behavior & .643 \\
\hline & & Passive behavior & -.004 \\
\hline & \multirow{4}{*}{ Sig. (1-tailed) } & VOC & \\
\hline & & Transformational behavior & .000 \\
\hline & & Transactional behavior & .000 \\
\hline & & Passive behavior & .489 \\
\hline & \multirow{4}{*}{$\mathrm{N}$} & VOC & 62 \\
\hline & & Transformational behavior & 62 \\
\hline & & Transactional behavior & 62 \\
\hline & & Passive behavior & 62 \\
\hline
\end{tabular}

Source: authors 
Table 10: The regression model for leadership behaviors and leaders' capacity to implement organizational change

\begin{tabular}{|c|c|c|c|c|c|c|c|c|c|c|}
\hline \multirow[b]{2}{*}{$\begin{array}{l}\text { Gender } \\
\text { of the } \\
\text { Director }\end{array}$} & & \multirow[b]{2}{*}{$\mathrm{R}$} & \multirow[b]{2}{*}{$\begin{array}{c}\mathrm{R} \\
\text { Square }\end{array}$} & \multirow[b]{2}{*}{$\begin{array}{l}\text { Adjusted } \\
\text { R Square }\end{array}$} & \multirow{2}{*}{$\begin{array}{l}\text { Std. } \\
\text { Error } \\
\text { of the } \\
\text { Estimate }\end{array}$} & \multicolumn{5}{|c|}{ Change Statistics } \\
\hline & & & & & & $\begin{array}{c}\text { R } \\
\text { Square } \\
\text { Change }\end{array}$ & $\begin{array}{c}\mathrm{F} \\
\text { Change }\end{array}$ & df1 & df2 & $\begin{array}{l}\text { Sig. F } \\
\text { Change }\end{array}$ \\
\hline$F$ & 1 & $.920^{\mathrm{a}}$ & .846 & .842 & .33612 & .846 & 243.497 & 3 & 133 & .000 \\
\hline M & 1 & $.815^{c}$ & .664 & .647 & .47377 & .664 & 38.290 & 3 & 58 & .000 \\
\hline \multicolumn{11}{|c|}{ a. Predictors: (Constant), Passive behavior, Transactional behavior, Transformational behavior } \\
\hline \multicolumn{11}{|c|}{ b. Dependent Variable: VOC } \\
\hline \multicolumn{11}{|c|}{ c. Predictors: (Constant), Q11.1, VTR, VTZ } \\
\hline
\end{tabular}

ANOVAa

\begin{tabular}{|c|c|c|c|c|c|c|c|}
\hline $\begin{array}{l}\text { Gender of } \\
\text { the Director }\end{array}$ & \multicolumn{2}{|c|}{ Model } & \multirow{2}{*}{$\begin{array}{l}\text { Sum of } \\
\text { Squares } \\
82.530\end{array}$} & \multirow{2}{*}{$\frac{d f}{3}$} & \multirow{2}{*}{$\begin{array}{l}\text { Mean } \\
\text { Square } \\
27.510\end{array}$} & \multirow{2}{*}{$\begin{array}{c}F \\
243.497\end{array}$} & \multirow{2}{*}{$\begin{array}{l}\text { Sig. } \\
\quad .000^{\mathrm{b}}\end{array}$} \\
\hline \multirow{3}{*}{$F$} & 1 & Regression & & & & & \\
\hline & Residual & 15.026 & 133 & .113 & & & \\
\hline & Total & 97.557 & 136 & & & & \\
\hline \multirow{3}{*}{$M$} & 1 & Regression & 25.783 & 3 & 8.594 & 38.290 & $.000^{c}$ \\
\hline & Residual & 13.018 & 58 & .224 & & & \\
\hline & Total & 38.802 & 61 & & & & \\
\hline
\end{tabular}

a. Dependent Variable: VOC

b. Predictors: (Constant), Passive behavior, Transactional behavior, Transformational behavior

c. Predictors: (Constant), Passive behavior, Transactional behavior, Transformational behavior

\begin{tabular}{|c|c|c|c|c|c|c|c|c|c|}
\hline \multicolumn{10}{|c|}{ Coefficientsa } \\
\hline \multirow{2}{*}{$\begin{array}{l}\text { Gender } \\
\text { of the } \\
\text { Director }\end{array}$} & \multirow{2}{*}{\multicolumn{2}{|c|}{$\begin{array}{c}\text { Model } \\
\text { B } \\
\text { Std. Error }\end{array}$}} & \multicolumn{3}{|c|}{$\begin{array}{l}\text { Unstandardized } \\
\text { Coefficients }\end{array}$} & \multicolumn{2}{|c|}{$\begin{array}{l}\text { Standardized } \\
\text { Coefficients }\end{array}$} & \multirow[t]{2}{*}{$t$} & \multirow[t]{2}{*}{ Sig. } \\
\hline & & & Beta & & & & & & \\
\hline \multirow{4}{*}{$\mathrm{F}$} & 1 & (Constant) & .428 & \multicolumn{2}{|r|}{.148} & & & 2.880 & .005 \\
\hline & & $\begin{array}{l}\text { Transformational } \\
\text { behavior }\end{array}$ & .623 & .047 & & .762 & 13.383 & .000 & \\
\hline & & Transactional behavior & .184 & .047 & & .211 & 3.927 & .000 & \\
\hline & & Passive behavior & .026 & .024 & & .040 & 1.082 & .281 & \\
\hline \multirow{4}{*}{ M } & 1 & (Constant) & .834 & \multicolumn{4}{|c|}{.294} & 2.832 & .006 \\
\hline & & $\begin{array}{l}\text { Transformational } \\
\text { behavior }\end{array}$ & .534 & .083 & & .645 & 6.416 & .000 & \\
\hline & & Transactional behavior & .187 & .080 & & .238 & 2.335 & .023 & \\
\hline & & Passive behavior & .006 & .046 & & .010 & .130 & .897 & \\
\hline
\end{tabular}

Source: authors 
The data showed that the variation of the independent variables (the leadership styles) influenced the variation of the dependent variable (organizational change) in a proportion of $84 \%$ in women's case and $66 \%$ in men's case. The Beta Standardized Coefficients indicated a strong relation between transformational behaviors and the capacity of change ( $76 \%$ in women's case and $64 \%$ in men's case). The data showed no significant relationship between passive and transactional behavior and leaders' capacity of change in men's case. In women's case, the relationship between transactional style and the capacity of change was positive, but weak.

\subsubsection{Institutional change}

The last hypothesis assumed that if civil servants' will perceive their leaders as being transformational leaders, it will be observed that they appreciate that the public institutions started to implement the change process. The hypothesis was validated by computing the frequencies of the civil servants' responses to the question: "In which phase of the changing process do you appreciate that the institution is?".

Table 11: The perception about the institutional change phase

\begin{tabular}{|c|c|c|c|}
\hline & & Frequency & Percent \\
\hline & At the beginning & 17 & 8.5 \\
\hline & Intermediary phase & 80 & 40.0 \\
\hline Valid & Advanced phase & 66 & 33.0 \\
\hline & No changes & 37 & 18.5 \\
\hline & Total & 200 & 100.0 \\
\hline
\end{tabular}

Source: authors

The frequencies of responses showed that the majority of the respondents $(40 \%)$ considered that the institution in which they were working was in an intermediary phase of change implementation and 33\% that the institutions were already in at advanced phase of implementing organizational change.

\subsection{Discussions}

The study revealed female leaders are perceived as being transformational leaders almost to a high extent. They also exhibit transactional traits from a medium to a high extent. The findings are in accordance with Bass and Avolio (1994) who considered women as transformational leaders, suited and capable of changing the contemporary organizations. Women also scored less than men at the passive leadership, as Eagly et al. (2003) suggested in their analysis, but the results are not in accordance with the authors' findings, female leaders being perceived less transformational as men. The perception about female leaders is that they exhibit almost the same leadership behav- 
iors than men do, even if they were not considered more transformational. The findings are in concordance with Foschi's $(1996,2000)$ theory regarding the double standards of competence. As female leaders managed to occupy positions with power of decision it is possible that they already proved their competencies and aptitudes. Consequently, gender does not influence anymore the way that female leaders are perceived. The fact that both types of leaders are perceived as behaving almost in the same manner is in accordance with Kanter's theory (1977) which suggested that men and women behave in a similar manner when they occupy the same hierarchic positions.

Even if, theoretically, there were small differences between the behaviors of the two compared groups, the fact that those differences were in men' favor could show that stereotypes are still present in the opinions of the public servants regarding their leaders' behaviors, but at lower intensity. The research showed that women are not perceived negatively and that they are considered suitable for leadership positions. The small difference of perception could indicate that the civil servants do not regard the female leaders as better than male leaders.

Also, the civil servants considered that the top executives had the capacity of changing the organizations from a medium to a high extent. Even though the study did not show that women as leaders are embracing change faster and more efficiently than men, the results suggested that in the future the female leadership advantage might appear. The fact that women exhibited mostly transformational behaviors has shown both their ability to change public organizations and their' important role in public sector reform. The strong relationship established between the transformational behaviors and the capacity of change indicates that women are open to change to a similar extent to men. The fact that the relationship was stronger in women's case indicates that if women continue to exhibit transformational behaviors, they can truly become better leaders. The research showed that women leader's characteristics have been positively appreciated by their' subordinates, which indicated as other authors suggested (Bass and Avolio, 1994; Dezso and Ross, 2008; Lowe and Kroeck, 1996) that the communal traits exhibited by women are suited for the modern public sector organization.

Another finding which is in women' favor is the fact that the civil servants considered that the organizational change process is influenced by gender to a medium extent, which might be a chance for women to prove that they could become innovative leaders.

Also, the majority of the civil servants (over $70 \%$ ) considered that the public organizations are in intermediary and advanced phases of the changing process which leads to the idea that leaders are approaching the managing process from a different perspective, including innovation and new manners of leading. 


\section{Conclusions and research limitations}

A limitation of the present research was the fact that not all the ministries from the Central Public Administration were involved in the study. Wider participation could have provided a better picture of the female leaders' capacities of implementing the organizational change.

Another limitation can reside in the unbalanced structure of the sample. The sample should have been more balanced with at least $60 \%$ of the respondents being led by female leaders and $40 \%$ by male leaders as to respect the structure of civil servants' population in the Romanian Public administration. Also, the massive presence of execution public servants into the sample (90\%) has possibly generated an uneven distribution of the answers. The balanced participation of execution and senior civil servants would have created a more realistic perception of leadership behaviors. As the civil servants from management positions are closer to the Directors/General Director their opinion might differ from the execution civil servants'. The study could be usefully conducted at the level of Local Authorities where the situation may be different as most of the Director positions are held by men. Another limitation could be the fact that the research is a study of perception, consequently it cannot be affirmed for certain that leaders' behaviors influence the process of implementing change, but rather that this is civil servants' personal opinion. Also, leaders' gender impact on organizational change process is also a matter of perception which reveal the presence of gender stereotypes inside the studied institutions, but at a low intensity. Therefore, these findings might not be similar in other organizations where gender stereotypes could be present at a lower intensity.

The main findings of the study have positive implications for female leaders in the context of public administration reform. Because women are the majority of the civil servants (66\% according to the National Agency of Civil Servants, 2019), a positive perception about their leading behaviors leads to the idea that they have the necessary qualities for occupying positions with high power of decision. Previous studies have shown that men have certain prejudices towards female leaders and would evaluate them in a less positive manner (Ayman et al., 2009; Norris and Wylie, 1995; Tomkiewicz and Adeyemi-Bello, 1995). Also, other authors have observed, that women would have negative perceptions of female leaders, more than men (Garcia-Retamero and LópezZafra, 2006; Parks-Stamm et al., 2008; Rudman, 1998) and for this reason, they would not associate effective leadership behaviors and characteristics with the feminine gender. In feminine working areas these prejudices could be more observed. In the institutions, the results are in women's favor because they are perceived in similar manners with their male counterparts. The study's results have positive implications for the Central Public Administration because it is important that civil servants' to be led by persons in whom they trust and about whom they a have positive opinions. This will make them accept easier the process of organizational change. 
Even if they are not considered better leaders than men, the differences of perception regarding the two types of leaders shows that women's position have improved and they acquired the necessary skills for leading in modern and transformational ways. Organizational change is part of the public administration reform, so if the positions with power of decision are held by effective leaders which try to use innovation as much as they can, it could be stated that the public institutions are starting to change and to react in a different manner as from the past.

The perception of the civil servants regarding the stage of change implementation in public institutions showed, that the public administration is starting to become an environment less and less characterized by rigidity and resistance to change. Even if bureaucracy still exists and the legislation should be adapted in order for the public administration to adapt and evolve in today's flexible environment, the fact that the civil servants from top management are trying to implement the management of change shows that the administrative reform started.

Even if the civil servants have not had a preference regarding their leaders' gender, they considered that gender is important when implementing organizational changes. Taking into consideration that women are being considered transformational leaders who approach the problems in innovative ways, they have the chance to be perceived as better leaders than men and female leadership advantage to be present into the public sector. For this to happen it is recommendable that female leaders adjust their leading behaviors. They should try to find more non-financial motivational techniques to inspire the civil servants and make them more involved in their activities. Also, they should exhibit more their communal traits and pay attention to their subordinates needs. As a motivation technique, female leaders should encourage and allow more the attendance of the civil servants at courses, trainings and experience exchanges with other public institutions. This will facilitate the know-how transfer, helping the organization to develop and implement the positive aspects from other organizations. The civil servants should be more involved in the decision-making process. The civil servants from top management should organize much more brainstorming sessions because the civil servants would feel useful and involved so the quality of their work would improve. Another aspect which should be changed is the fact that leaders tend to pursue errors and mistakes to a high extent, which will not lead to a high quality of work and will not improve the relationships between leaders and subordinates.

In conclusion, because the female leaders from Romania's Central Public Administration are considered transformational leaders, who use innovation and try to implement the management of change, they have the opportunity to become better leaders in the future. The civil servants' perception that top managers' gender influences the organizational change process is in men's favor and suggests that women should improve their leading behaviors trying to exhibit more, their communal traits. The positive perception of female 
leaders shows that they are capable of reforming the public organizations, but they still have to show more, their abilities and competencies.

Acknowledgment: This work was supported by a grant of the Ministry of Research and Innovation, CNCS - UEFISCDI, project number PN-III-P4-ID-PCCF-2016-0166, within the PNCDI III project "ReGrowEU - Advancing groundbreaking research in regional growth and development theories, through a resilience approach: towards a convergent, balanced and sustainable European Union". 


\section{References}

Abele, A. (2003). The dynamics of masculine-agentic and feminine communal traits: Findings from a prospective study. Journal of Personality and Social Psychology, 85, pp. 768-776.

Avolio, B. J. (1999). Full leadership development: Building the vital forces in organizations. Thousands Oaks, CA: Sage.

Avolio, B. J. and Bass, B. M. (2004). Multifactor Leadership Questionnaire: third edition. Manual and Sample Set, Redwood City: Mind Garden.

Bakan, D. (1966). The duality of human existence: An essay on psychology and religion. Chicago: Rand McNally.

Bass, B. M. (1985). Leadership and performance beyond expectations. New York: Free Press.

Bass, B. M. (1999). Two decades of research and development in transformational leadership. European Journal of Work and Organizational Psychology, 8, pp. 9-32.

Bass, B. M. (2008). The Bass handbook of leadership: Theory, research, \& managerial applications (4th ed.). New York: Free Press.

Bass, B. M. and Avolio, B. J. (1990). Multifactor leadership questionnaire. Palo Alto, CA: Consulting Psychologist Press.

Bass, B. M. and Avolio, B. J. (1993). Transformational leadership: A response to critiques. In M.M. Chemers and R. Ayman, eds., Leadership theory and research: Perspectives and directions. San Diego, CA: Academic Press, pp. 49-80.

Bass, B. and Avolio, B. (1994), Shatter the glass ceiling: woman may make better managers, Human Resource Management, 33(4), pp. 549-560.

Bass, B. M. and Avolio, B. J. (2000). MLQ Multifactor Leadership Questionnaire. Redwood City: Mind Garden.

Bass, B. M. and Riggio, R. E. (2006). Transformational leadership (2nd ed.). Mahwah: Lawrence Erlbaum Associates Publishers.

Bass, B. M. and Steidlmeier, P. (1999). Ethics, character, and authentic transformational leadership behavior. Leadership Quarterly, 10, pp. 181-217.

Berger, J. et al. (1977). Status Characteristics and Social Interaction: An Expectation States Approach. New York: Elsevier Scientific Publishing Co.

Bibu, N. and Moş, L. (2012). Leadership Style in the Romanian Public Institutions - the Case of City Halls. Review of International Comparative Management, 13(1), pp. 81-87.

Blau, P. (1964). Exchange and Power in Social Life. New York: Wiley.

Book, E. W. (2000). Why the best man for the job is a woman? New York: Harper Collins.

Brown, S.L. and Eisenhardt K.M. (1997). The art of continuous change: linking complexity theory and time-paced evolution in relentlessly shifting organizations. Administrative Sciences Quarterly, 42, pp. 1-34.

Carter, M. Z. et al. (2012). Transformational leadership, relationship quality, and employee performance during continuous incremental organizational change. Journal of Organizational Behavior, 34, pp. 942-958.

Conger, J. A. (1999). Charismatic and transformational leadership in organizations: An insider's perspective on these developing streams of research. The Leadership Quarterly, 10(2), pp. 145-179. 
Cropanzano, R. and Mitchell, M.S. (2005). Social exchange theory: an interdisciplinary review, Journal of Management, 31, pp. 874-900.

Dezso, C. L. and Ross, D. G. (2008). Girl power: Female participation in top management and firm performance. At <http://ssrn.com/abstract1088182>, accessed 1 February 2020.

Eagly, A. H. (2007). Female leadership advantage and disadvantage: Resolving the contradictions. Psychology of Women Quarterly, 31, pp. 1- 12.

Eagly, A. H. and Carli, L. L. (2003a). The female leadership advantage: An evaluation of the evidence. Leadership Quarterly, 14, pp. 807-834.

Eagly, A. H. and Carli, L. L. (2003b). Finding gender advantage and disadvantage: Systematic research integration is the solution. Leadership Quarterly, 14, pp. 851-859.

Eagly, A. H. and Johnson, B. T. (1990). Gender and leadership style: A metaanalysis. Psychological Bulletin, 108, pp. 233-256.

Eagly, A. H. and Johannesen-Schmidt, M. C. (2001). The leadership styles of women and men. The Journal of Social Issues, 57, pp. 781-797.

Eagly, A. H., Johannesen-Schmidt, M. C. and Van Engen, M. (2003). Transformational, transactional and laissez-faire leadership styles: A meta-analysis comparing women and men. Psychological Bulletin, 129, pp. 569-591.

Eagly, A. H. and Karau, S. J. (1991). Gender and the emergence of leaders: A meta-analysis. Journal of Personality and Social Psychology, 60, pp. 685-710.

Eagly, A. H. and Karau, S. J. (2002). Role congruity theory of prejudice toward female leaders. Psychological Review, 109, pp. 573-598.

Eagly, A. H., Karau, S. J. and Makhijani, M. G. (1995). Gender and the effectiveness of leaders: A meta-analysis. Psychological Bulletin, 117, pp. 125-145.

Eagly, A. H., Makhijani, M. G. and Klonsky, B. G. (1992). Gender and the evaluation of leaders: A meta-analysis. Psychological Bulletin, 111, pp. 3-22.

Feldman, M. S. and Pentland, B. T. (2003). Reconceptualizing organizational routines as a source of flexibility and change. Administrative Science Quarterly, 48, pp. 94-118.

Filip, A. (2015). Analiza stilului de leadership în administrația publică din România, Revista Transilvană de Științe Administrative, 1(36), pp. 35-50.

Fiske, S. T. and Stevens, L. E. (1993). What's so special about sex? Gender stereotyping and discrimination. In S. Oskamp and M. Costanzo, eds., Gender issues in contemporary society: Applied social psychology annual. Newbury, CA: Sage. pp. 173-196.

Foschi, M. (1996). Double standards in the evaluation of men and women. Social Psychology Quarterly, 59, pp. 237-254.

Foschi, M. (2000). Double standards for competence: Theory and research. Annual Review of Sociology, 26, pp. 21-42.

García Morales, V.J. et al. (2008a). The effects of transformational leadership on organizational performance through knowledge and innovation. British Journal of Management, 19(4), pp. 299-319.

García Morales, V.J., Matías Reche F. and Hurtado Torres N., (2008b) Influence of transformational leadership on organizational innovation and performance depending on the level of organizational learning in the pharmaceutical sector. Journal of Organizational Change Management, 21(2), pp. 188-212. 
Gerstner, C.R. and Day, D.V. (1997). Meta-analytic review of leader-member exchange theory: correlates and construct issues. Journal of Applied Psychology, 82, pp. 827-844.

Graen, G.B. and Uhl-Bien, M. (1995). Relationship based approach to leadershipdevelopment of leader-member exchange (LMX) theory of leadership over 25 years - applying a multilevel multidomain perspective. Leadership Quarterly, 6, pp. 219-247.

Hater, J.J. and Bass, B.M. (1988). Superiors' evaluations and subordinates' perceptions of transformational and transactional leadership. Journal of Applied Psychology, 73, pp. 695-702.

Heilman, M. E. (2001). Description and prescription: How gender stereotypes prevent women's ascent up the organizational ladder. Journal of Social Issues, 57, pp. 657-674.

Helgesen, S. (1990). The female advantage: Women's ways of leadership. New York: Doubleday/Currency.

Hințea, C.E. (2007). Management public. Cluj-Napoca: Accent.

Hințea, C. (2015). Transformational Leadership and Performance in the Romanian Public Administration. Revista de cercetare și intervenție socială, 51, pp. 103-121.

Howell, J. M. and Hall-Merenda, K. E. (1999). The ties that bind: The impact of leader-member exchange, transformational and transactional leadership, and distance on predicting follower performance. Journal of Applied Psychology, 84, pp. 680-694.

Ilies R, Nahrgang J.D. and Morgeson F.P. (2007). Leader-member exchange and citizenship behaviors: a meta-analysis. Journal of Applied Psychology, 92, pp. 269-277.

Jogulu, U. D. and Wood, G. J. (2006). The role of leadership theory in raising the profile of women in management. Equal opportunities international, 25(4), pp. 236-250.

Kanfer, R. and Ackerman, P. L. (1989). Dynamics of skill acquisition: Building a bridge between abilities and motivation. In R. J. Sternberg, ed., Advances in the psychology of human intelligence. Hillsdale, NJ: Erlbaum. pp. 83-134.

Kanter, R. M. (1977). Men and women of the corporation. New York: Basic Books.

Kuhnert, K. (1994). Transformational leadership: developing people through delegation. In B.M. Bass, and B.J. Avolio, eds., Improving organizational effectiveness through transformational leadership. Thousand Oaks, CA: Sage. pp. 10-25.

Liu, X. and Batt, R. (2010). How supervisors influence performance: A multilevel study of coaching and group management in technology-mediated services. Personnel Psychology, 63, pp. 265-298.

Loden, M. (1985). Feminine leadership or how to succeed in business without being one of the boys. New York: Times Books.

Lowe, K. B., Kroeck, K. G. and Sivasubramaniam, N. (1996). Effectiveness correlates of transformational and transactional leadership: A meta-analytic review of the MLQ literature. Leadership Quarterly, 7, pp. 385-425.

Macarie, F.C. (2006). Women in the Management of Public Organization. ClujNapoca: Babes-Bolyai University. 
Macarie, F. and Moldovan, O. (2012). Gender Discrimination in Management: Theoretical and Empirical Perspectives. Transylvanian Review of Administrative Sciences, 35E, pp. 153-172.

Macarie, F.C., Creța, S. and Tuța, I. (2008). Gender Impact on Public Organizations' Culture. Transylvanian Review of Administrative Sciences, 4(24), pp. 64-76.

McCleskey, J.A. (2014). Situational, transformational, and transactional leadership and leadership development. Journal of Business Studies Quarterly, 5(4), pp. 117-130.

Moldovan, O. (2016). Representative Bureaucracy in Romania? Gender and Leadership in Central Public Administration. Transilvanian Review of Administrative Sciences, 48, pp. 66-83.

Mora, C. and Țiclău, T. (2013). Leadership in the Public Sector. București: Tritonic. Morrison, A. M., White, R. P. and Van Velsor, E. (1987). Breaking the glass ceiling. Reading, MA: Addison-Wesley.

National Agency of Civil Sevants, (2019), Raportul privind managementul funcției publice și al funcționarilor publici pe anul 2018. At <http://www. anfp.gov.ro/R/Doc/2019/rapoarte\%202019/Raport\%20privind\%20 managementul\%20func\%C5\%A3iei\%20publice\%20\%C5\%9Fi\%20al\%20 func\%C5\%A3ionarilor\%20publici\%20pentru\%20anul\%202018.pdf>, accessed 2 February 2020.

Omar, A. and Davidson, M.J. (2001), Women in management: a comparative cross-cultural overview. International Journal of Cross-Cultural Management, 8(3/4), pp. 35-67.

Pawar, B.S. and Eastman, K.K. (1997). The nature and implications of contextual influences on transformational leadership: A conceptual examination. Academy of Management Review, 22, pp. 80-109.

Powell, G. and Butterfield, D. (1994). Investigating the "glass ceiling" phenomenon: An empirical study of actual promotions to top management. Academy of Management Journal, 37, pp. 68-86.

Powell, G.N. and Graves, L.M. (2003). Women and Men in Management. Newbury Park: Sage Publications.

Profiroiu, A. G. and Nastacă, C. C. (2018), Leadership and Gender Equality in Central Public Administration of Romania. Proceedings of 32nd IBIMA International Conference, Seville, Spain, 15-16 November 2018, 2412-2427, ISBN: 978-0-9998551-1-9.

Profiroiu, C.M., Profiroiu, A. and Nastacã, C.C. (2020). Leadership and gender in the Romanian prefectures. Management Research and Practice, 12(2), pp. 25-38.

Ridgeway, C. L. (1997). Where do status beliefs come from? New developments. In J. Szmatka, J. Skvoretz, and J. Berger, eds., Status, networks, and structure, pp. 137-158. Stanford, CA: Stanford University Press.

Ridgeway, C.L. (2011). Framed by Gender: How Gender Inequality Persists in the Modern World. New York: Oxford University Press Carroll.

Romanian Government. (2019). The Administrative Code. Official Journal of Romania, No. 555 from 5 July 2019.

Rosener, J. B. (1995). America's competitive secret: Utilizing women as a management strategy. New York: Oxford University Press. 
Rosette, A.S. and Tost, L.P. (2010). Agentic women and communal leadership: How role prescriptions confer advantage to top women leaders. Journal of Applied Psychology, 95, pp. 221-235.

Sadeghi, A. and Pihie, Z. (2012). Transformational leadership and its predictive effects on leadership effectiveness. International Journal of Business and Social Science, 3(7), pp. 186-197.

Stănescu, D.F. and Roșca, A.C. (2010) Transformational Leadership in the Public Sector - not a Bedtime Story. Romanian Journal of Communication and Public Relations, 12(2), pp. 95-107.

Şandor, S.D., Macarie, F.C. and Creţa, S.C. (2011). Gender Equality in Romanian Local Public Institutions. Transylvanian Review of Administrative Sciences, 34E, pp. 217-228.

Țiclău, T. (2012). Leadership transformațional în sectorul public, PhD Thesis. Babeş-Bolyai University: Cluj-Napoca.

Ticlau T., Balica D. and Mora, C. (2013). Transformational leadership in Romania's local public administration. The 2013 NISPAcee conference (Bratislava: NISPAcee).

Țiclău, T. and Hințea, C. (2016). Administrative leadership and situational antecedents in the Romanian public administration. Lex Localis, 14(1), pp. $133-156$.

Vecchio, R. P. (2002). Leadership and gender advantage. Leadership Quarterly, 13, pp. 643-671.

Vecchio, R. P. (2003). In search of gender advantage. Leadership Quarterly, 14, pp. 835-850.

Van Engen, M.L., van der Leeden, R. and Willemsen, T.M. (2001). Gender, context and leadership styles: A field study. Journal of Occupational and Organizational Psychology, 20, p. 74.

Weick, K.E. and R. Quinn. (1999). Organizational Change and Development. Annual Review of Psychology, 50, pp. 361-386.

Wilson, K. S., Sin, H. P. and Conlon, D. E. (2010). What about the leader in leadermember exchange? The impact of resource exchanges and substitutability on the leader. Academy of Management Review, 35, pp. 358-372. 